\title{
AKUMULASI LOGAM BERAT Pb DALAM TUBUH UDANG WINDU (Penaeus monodon) PADA KONDISI SALINITAS BERBEDA
}

\author{
Petrus Rani Pong-Masak dan Rachmansyah
}

\begin{abstract}
ABSTRAK
Penelitian ini bertujuan untuk mengetahui pengaruh tingkat salinitas media pemeliharaan terhadap konsentrasi akumulasi logam $\mathrm{Pb}$ dalam tubuh udang windu (Penaeus monodon). Penelitian dilakukan dalam skala laboratorium menggunakan rancangan acak lengkap dengan perlakuan salinitas $10,15,20$, dan 25 ppt masing-masing diulang tiga kali. Setiap unit percobaan diaplikasikan dengan logam berat $\mathrm{Pb}$ dalam bentuk senyawa $\left(\mathrm{CH}_{3} \mathrm{COO}\right)_{2} \cdot \mathrm{Pb} \cdot 3 \mathrm{H}_{2} \mathrm{O}$ sebesar 2 $\mathrm{mg} / \mathrm{L}$. Konsentrasi akumulasi $\mathrm{Pb}$ dalam tubuh udang windu dianalisis dengan Spektrofotometer Serapan Atom (AAS). Korelasi tingkat salinitas perlakuan dengan konsentrasi akumulasi $\mathrm{Pb}$ dalam tubuh udang windu dianalisis secara regresi. Hasil penelitian menunjukkan bahwa salinitas berpengaruh nyata terhadap tingkat akumulasi $\mathrm{Pb}$. Semakin tinggi salinitas maka konsentrasi akumulasi $\mathrm{Pb}$ semakin rendah. Sedangkan organ tubuh yang paling berpotensi mengakumulasi $\mathrm{Pb}$ adalah organ dalam, kemudian exoskeleton dan terendah dalam daging.
\end{abstract}

ABSTRACT: Heavy metal Pb accumulation on tiger prawn (Penaeus monodon) body in different salinity levels. By: Petrus Rani Pong-Masak and Rachmansyah

This research aimed to understand the implication of developing media salinity levels toward Pb metal accumulation concentrated on tiger prawn body (Penaeus monodon). The research was conducted at laboratory scale using complete random design with salinity treatments of 10, 15, 20, and $25 \mathrm{ppt}$ repeated for three times. Every treatment unit was applicated with $\mathrm{Pb}$ heavy metal in compound form $\left(\mathrm{CH}_{3} \mathrm{COO}\right)_{2} . \mathrm{Pb} \cdot 3 \mathrm{H}_{2} \mathrm{O}$ in the amount of $2 \mathrm{mg} / \mathrm{L}$. Pb accumulated concentration on tiger prawn body was analized by Atomic Absorption Spectrophotometer (AAS). Correlation of the treated salinity levels with $\mathrm{Pb}$ accumulated concentration on tiger prawn body was analized by regression. Research results showed that salinity significantly effected the $\mathrm{Pb}$ accumulation level. The higher salinities the lower Pb accumulation concentration. Nevertheles, while part of the body which was most potential to accumulate $\mathrm{Pb}$ was the cirus viscerum, followed with exosceleton while the lowest was in the meat.

\section{KEYWORDS: accumulation, Pb, salinity, tiger prawn}

\section{PENDAHULUAN}

Secara alamiah Plumbum (Pb) masuk ke dalam perairan melalui pengkristalan di udara dengan bantuan air hujan dan proses korosifikasi dari batuan mineral akibat hempasan gelombang dan angin. Sumber dari dampak kegiatan manusia di antaranya limbah industri yang berkaitan dengan $\mathrm{Pb}$, air buangan dari pertambangan biji $\mathrm{Pb}$, dan buangan sisa baterai. Masuknya $\mathrm{Pb}$ secara kontinyu ke dalam perairan akan meningkatkan konsentrasinya, sehingga dapat menyebabkan bioakumulasi dan biomagnifikasi pada biota perairan, bahkan dapat membunuh ikan-ikan apabila dalam air mencapai konsentrasi $188 \mathrm{mg} / \mathrm{L}$ (Palar, 1994).

Kondisi demikian selain berdampak langsung terhadap biota budi daya, juga akan menyebabkan punahnya satu atau beberapa spesies tertentu yang berdampak pada ketidakseimbangan ekosistem akibat dominansi spesies tertentu. Apabila dampak negatif tersebut tidak diantisipasi akan mengurangi sumber daya hayati perairan, daya dukung lahan, serta munculnya hama atau penyakit yang tidak terkendali. Selain itu, dampak bahan-bahan beracun yang terkonsentrasi dalam biota perairan sebagai sumber pangan dapat mengancam kesehatan manusia sebagai konsumen akhir. Naid \& Seniwati (1998) menyatakan bahwa keracunan kronik $\mathrm{Pb}$ diindikasikan dengan gejala-gejala seperti anemia, kram usus, kelelahan, nafsu makan hilang, dan pada anak-anak dapat merusak otak.

Pada konsentrasi tertentu, Pb memiliki berbagai manfaat dalam kehidupan sehari-hari terhadap kesehatan manusia maupun dalam mendukung kemajuan IImu Pengetahuan dan Teknologi IPTEK di berbagai sektor pembangunan. Pb merupakan komponen penting dalam pembentukan tulang (Huheey, 1983), namun dalam dosis yang tinggi $\mathrm{Pb}$ adalah logam beracun dan berbahaya terhadap penyumbatan sel-sel darah merah dan mempengaruhi

\footnotetext{
-) Peneliti pada Balai Penelitian Perikanan Pantai, Maros
} 
anggota tubuh lainnya. Gan et al. (1981) menyatakan bahwa keracunan $\mathrm{Pb}$ dalam darah dapat menyebabkan anemia karena dapat bereaksi dengan enzim yang berhubungan dengan sintesis butir darah merah.

Udang windu sebagai komoditas perikanan bernilai ekonomi, sangat rentan terhadap pencemaran dan perubahan lingkungan. Salah satu parameter kualitas perairan yang berpengaruh terhadap kehidupan udang windu adalah salinitas. Salinitas di perairan tambak sangat berfluktuasi akibat proses hidrodinamika perairan pesisir seperti pasang surut, presipitasi, evaporasi, dan rembesan. Kinne (1964) melaporkan bahwa fluktuasi salinitas dapat mempengaruhi osmoregulasi dan adaptasi osmotik organisme air. Hasil penelitian yang dilaporkan Connel (1995) diketahui bahwa penurunan salinitas dari $30 \mathrm{ppt}$ ke 20 ppt akan menghasilkan kenaikan $400 \%$ bioakumulasi Kadmium (Cd) oleh bivalva laut. Selanjutnya Denton \& Jones (1982) menyatakan bahwa organisme perairan lebih peka terhadap logam berat pada suhu tinggi dan salinitas rendah. Dengan demikian peran salinitas sangat penting untuk kehidupan organisme perairan.

Berdasarkan uraian di atas diduga tingkat dan laju penyerapan logam berat $\mathrm{Pb}$ oleh udang windu dalam jaringan tubuhnya berbeda pada tingkatan salinitas pemeliharaan. Penelitian ini bertujuan mengetahui pengaruh salinitas media pemeliharaan terhadap laju akumulasi logam berat $\mathrm{Pb}$ dalam tubuh udang windu (Penaeus monodon). Hasil penelitian dapat menjadi informasi bagi pengelolaan sumber daya perairan untuk mendukung pengelolaan dan teknis budi daya udang windu. Selain itu data yang diperoleh dapat berupa acuan dalam mengantisipasi keamanan pangan yang bersumber dari produk perairan pesisir.

\section{BAHAN DAN METODE}

Penelitian dilakukan di Instalasi Tambak Percobaan Maranak, Balai Penelitian Perikanan Pantai Maros, Sulawesi Selatan. Kegiatan dimulai dengan membersihkan wadah yaitu fibreglass bentuk segi empat bervolume $100 \mathrm{~L}$ sebanyak 12 buah, kemudian setiap wadah diisi air sebanyak $75 \mathrm{~L}$ berdasarkan tingkat salinitas perlakuan. Air yang digunakan terlebih dahulu disaring menggunakan filter bag dan diaerasi selama 3 hari secara kontinyu dalam wadah penampungan. Instalasi aerasi dipasang untuk memasok kebutuhan oksigen bagi kelayakan hidup hewan uji. Hewan uji yang digunakan adalah udang windu (Penaeus monodon) dengan kisaran bobot 35$40 \mathrm{~g}$ yang diperoleh dari tambak petani sekitar lokasi penelitian. Proses pengumpulan udang dengan alat tangkap sero kemudian dibawa ke laboratorium dalam kantong plastik transparan yang diberi oksigen.
Adaptasi dilakukan selama tujuh hari untuk memulihkan stress dan penyesuaian salinitas perlakuan dalam kondisi laboratorium.

Sebelum percobaan dimulai, sampling awal dilakukan untuk mengetahui konsentrasi awal $\mathrm{Pb}$ dalam tubuh udang windu. Percobaan disusun dalam rancangan acak lengkap ( $R A L$ ) dengan empat perlakuan, yaitu salinitas $10,15,20$, dan $25 \mathrm{ppt}$, dan masing-masing perlakuan diulang tiga kali. Ke dalam setiap wadah dimasukkan udang windu sebanyak 15 ekor secara acak. Setelah hewan uji teraklimatisasi dan layak uji, ditandai dengan pergerakan normal dan aktif makan, maka logam berat $\mathrm{Pb}$ dalam bentuk senyawa $\left(\mathrm{CH}_{3} \mathrm{COO}\right)_{2} \cdot \mathrm{Pb} .3 \mathrm{H}_{2} \mathrm{O}$ diformulasikan ke dalam setiap wadah pada konsentrasi $2 \mathrm{mg} / \mathrm{L}$. Konsentrasi tersebut diturunkan $15 \%$ dari nilai $\mathrm{LC}_{50}$ 96 jam $\mathrm{Pb}$ terhadap benur windu sebesar $14,53 \mathrm{mg} / \mathrm{L}$ berdasarkan penelitian sebelumnya (Rachmansyah et al., 1998). Selama pemeliharaan, hewan uji diberi pakan komersial sebanyak $5 \%$ dari bobot biomassa per hari dengan frekuensi pernberian empat kali. Untuk menjaga kestabilan konsentrasi $\mathrm{Pb}$ dan kelayakan kualitas media, maka dilakukan pergantian air sebanyak $50 \%$ /hari dari volume setiap wadah dengan tetap mempertahankan konsentrasi awal $\mathrm{Pb}$ dalam media sebesar $2 \mathrm{mg} / \mathrm{L}$. Pemeliharaan berlangsung selama 9 hari, di mana pengambilan sampel dilakukan pada 3,6, dan 9 hari setelah aplikasi masing-masing sebanyak 4 ekor. Sampel dipreservasi dalam cool box dan dibawa ke laboratorium untuk analisis konsentrasi $\mathrm{Pb}$ dalam tubuh udang windu menggunakan Spektrofotometer Serapan Atom (AAS) model GBC double beam 902. Proses preservasi dan analisis sampel berpedoman pada Khopkar (1990). Sampel dipisahkan dan dianalisis berdasarkan organ yaitu otak dan usus (citus viscerum), daging (meat), dan kulit (exosceleton). Untuk menentukan konsentrasi Pb dari hasil analisis dalam setiap organ tubuh digunakan rumus sebagai berikut:

$$
c=\frac{V \times c}{a}
$$

dengan:

$\mathrm{C}=$ konsentrasi $\mathrm{Pb}$ dalam organ tubuh udang windu $(\mathrm{mg} / \mathrm{g})$

$\mathrm{V}=$ volume penepatan $(\mathrm{mL})$

$c=$ konsentrasi larutan contoh $(\mathrm{mg} / \mathrm{g})$

$\mathrm{a}=$ bobot sampel $(\mathrm{g})$

Untuk mengetahui pengaruh perlakuan, data dianalisis secara ragam, sedangkan keeratan hubungan antara tingkat salinitas dengan kandungan logam $\mathrm{Pb}$ dalam tubuh udang dianalisis secara regresi.

Selama pemeliharaan berlangsung dilakukan pengukuran kualitas media pemeliharaan untuk 
memantau kelayakan media uji terhadap kehidupan udang windu. Parameter kualitas air yang diukur serta metode pengukurannya adalah temperatur $\left({ }^{\circ} \mathrm{C}\right)$ Triplescale Patinum RTD thermometer J-8519-00 CP (-191 sampai $\left.407^{\circ} \mathrm{C}\right)$; $\mathrm{pH}$ LED digi-sense $\mathrm{pH}$ meter model C-5513-55 CP; oksigen terlarut (mg/L) DO-meter model J-5513-55 CP (0,00-19.00 mg/L)

\section{HASIL DAN BAHASAN}

Hasil analisis pengaruh $\mathrm{Pb}$ dalam organ udang windu pada tingkat salinitas berbeda diperlihatkan pada Tabel 1, sedangkan laju akumulasi Pb dalam organ udang windu selama aplikasi 9 hari diperlihatkan pada Gambar 1, 2, dan 3. Secara umum konsentrasi $\mathrm{Pb}$ dalam setiap organ menunjukkan korelasi positif dengan waktu aplikasi di mana konsentrasi semakin meningkat dengan semakin lamanya waktu aplikasi. pat bahwa akumulasi terjadi karena logam berat dalam tubuh organisme cenderung membentuk senyawa kompleks dengan zat-zat organik yang terdapat dalam tubuh organisme. Dengan demikian berarti terfiksasi dan tidak diekskresikan oleh organisme bersangkutan.

Masuknya logam berat ke dalam perairan secara langsung akan mempengaruhi proses bioakumulasi dan apabila melebihi konsentrasi alamiah akan memberikan pengaruh yang sangat merugikan bagi organisme budi daya bahkan dapat mengancam kesehatan manusia. Menurut Casper (1975) dalam Hutagalung (1991), bahwa secara alamiah logam berat masuk ke dalam organisme laut melalui rantai makanan, sehingga pemangsa yang berukuran lebih besar seperti ikan mengandung logam berat yang tinggi, tetapi kandungan tertinggi umumnya ditemukan dalam invertebrata jenis filter feeder dan dapat terjadi pada manusia sebagai konsumen terakhir.

Tabel 1. Regresilinier pengaruh $\mathrm{Pb}$ dalam organ udang windu pada salinitas berbeda Table 1. Linier regression of $\mathrm{Pb}$ effect in tiger prawn organ at different salinity

\begin{tabular}{|c|c|c|c|}
\hline $\begin{array}{l}\text { Organ } \\
\text { Organ }\end{array}$ & $\begin{array}{l}\text { Regresi linier } \\
\text { Linier regression }\end{array}$ & F-cal & $r^{2}$ \\
\hline Daging/Meat & $Y=4.6452-0.2032 X_{1}+0.3921 X_{2}$ & $43.86(p=0.00)$ & 0.9069 \\
\hline Karapaks/Exosceleton & $Y=25.756-0.9886 X_{1}+2.0396 X_{2}$ & $45.08(p=0.00)$ & 0.9092 \\
\hline $\begin{array}{l}\text { Otak dan usus } \\
\text { Brain and citus viscerum }\end{array}$ & $Y=24.776-1.88769 X_{1}+6.8392 X_{2}$ & $47.22(p=0.00)$ & 0.9130 \\
\hline \multirow[t]{2}{*}{ Keterangan: } & Salinitas & & \\
\hline & Waktu pemaparan & & \\
\hline \multirow[t]{2}{*}{ Note: } & Salinity & & \\
\hline & Exposure time & & \\
\hline
\end{tabular}

Penyerapan Pb yang terus meningkat dalam tubuh udang windu dimungkinkan oleh beberapa jalur penyerapan antara lain melalui pakan, penyerapan langsung dari air, dan proses difusi melalui karapas yang didukung oleh faktor-faktor internal maupun eksternal udang windu. $\mathrm{Pb}$ yang masuk ke dalam sistem metabolisme akan mengalami proses sirkulasi melalui peredaran darah, sehingga menyebar dan akan terkonsentrasi dalam setiap organ sebesar kapasitas kerja dan fungsinya. Selain itu, adanya proses osmoregulasi dan difusi melalui kulit memungkinkan peningkatan dalam organ karapas.

Kemampuan absorpsi $\mathrm{Pb}$ yang lebih tinggi daripada laju eliminasi juga merupakan faktor penentu semakin tingginya akumulasi, di mana proses detoksifikasi oleh udang windu terhadap $\mathrm{Pb}$ yang terserap lebih kecil. Loomis (1978) menyatakan bahwa kadar zat kimia dalam tubuh suatu hewan akan stabil dalam suatu selang waktu bila laju absorpsi sama dengan laju eliminasinya. Selanjutnya Waldichuk (1974) berpenda-
Perubahan salinitas berpengaruh secara langsung terhadap kemampuan akumulasi $\mathrm{Pb}$ pada setiap organ udang windu. Hasil analisis dalam organ daging menunjukkan bahwa peningkatan konsentrasi $\mathrm{Pb}$ terjadi dengan semakin turunnya salinitas. Pada penurunan salinitas dari 25 ppt ke 20 ppt dan 15 ppt untuk setiap waktu pengamatan menunjukkan penurunan yang relatif kecil, kemudian pada salinitas 10 ppt laju peningkatan akumulasi $\mathrm{Pb}$ semakin meningkat (Gambar 1).

Konsentrasi $\mathrm{Pb}$ yang terus meningkat akan menyebabkan kerusakan dalam jaringan udang windu terutama menghambat fungsi masing-masing organ. Loomis (1978) berpendapat bahwa apabila dosis tunggal suatu zat kimia mengubah fungsi bagian dalam dari seekor hewan kemudian pemberian zat tersebut dihentikan, maka mekanisme biokimia, fungsi, dan struktur apapun yang telah berubah biasanya kembali ke normal dalam waktu tertentu, setelah zat kimia tersebut meninggalkan hewannya 


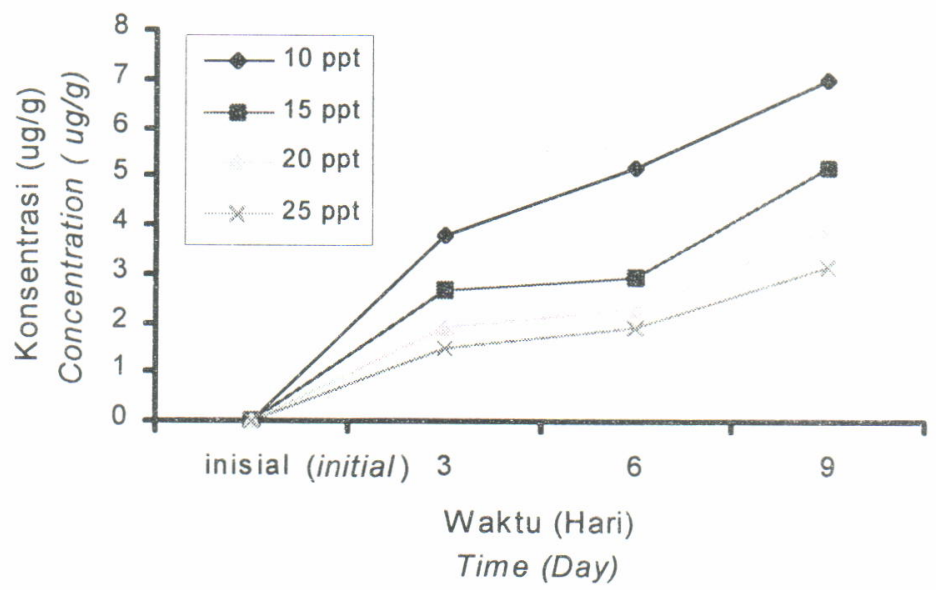

Gambar 1. Akumulasi Pb daiam daging udang windu pada salinitas berbeda

Figure 1. Accumulation of $\mathrm{Pb}$ in tiger prawn meat on different salinity

secara ekskresi atau detoksikasi, yaitu dengan mengganti sel-sel yang rusak. Narnun jika kerusakan sedemikian besar akibat pemberian secara terusmenerus akan menyebabkan penumpukan, sehingga efek toksiknya lebih sensitif.

Determinasi konsentrasi $\mathrm{Pb}$ selama pemeliharaan pada organ karapaks memperlihatkan bahwa tingkatan salinitas perlakuan mempunyai laju akumulasi berbeda (Gambar 2). Hal tersebut dimungkinkan oleh fisiologi udang windu yang dalam waktu tertentu mengalami proses moulting, sehingga $\mathrm{Pb}$ yang masuk
Akumulasi $\mathrm{Pb}$ pada organ dalam udang windu memperlihatkan bahwa konsentrasi sebelum aplikasi sampai 3 hari setelah aplikasi relatif sama dan bahkan pada konsentrasi 25 ppt lebih rendah pada 3 hari setelah aplikasi, kemudian meningkat pada 6 dan 9 hari setelah aplikasi (Gambar 3)

Peningkatan konsentrasi $\mathrm{Pb}$ pada salinitas rendah diduga disebabkan oleh masuknya air melalui proses osmosis pada kondisi salinitas rendah, sehingga memungkinkan masuknya ion-ion mineral termasuk $\mathrm{Pb}$ yang terkandung dalam air dan sebaliknya.

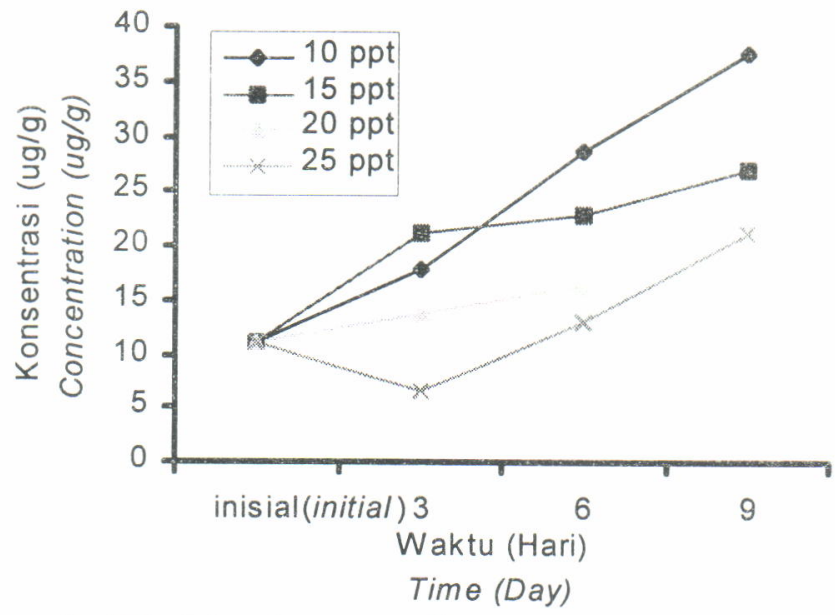

Gambar 2. Akumulasi Pb dalam karapas udang windu pada salinitas berbeda

Figure 2. Accumulation of $\mathrm{Pb}$ in tiger prawn exosceleton on different salinity

dan terkonsentrasi pada karapas akan ikut terbuang pada saat moulting. Pada perlakuan salinitas $25 \mathrm{ppt}$ terlihat bahwa konsentrasi $\mathrm{Pb}$ pada hari ketiga setelah aplikasi lebih rendah dibandingkan sebelum aplikasi, kemudian meningkat terus sampai penurunan salinitas 15 ppt dan pada salinitas 10 ppt konsentrasi $\mathrm{Pb}$ mengalami penurunan. Pada pemaparan 6 dan 9 hari memperlihatkan laju peningkatan konsentrasi dengan semakin turunnya salinitas.
Sumeru \& Anna (1992) berpendapat bahwa udang windu dalam adaptasinya terhadap lingkungan air bersalinitas tinggi akan banyak kehilangan air melalui difusi keluar tubuhnya, sehingga memungkinkan ionion yang masuk bersama air atau makanan tersimpan dalam organ-organ tubuhnya. Pernyataan tersebut didukung oleh Putri (2001) bahwa logam berat di dalam perairan diikat oleh senyawa organik dan anorganik yang terkandung dalam air. Proses pengikatan oleh 


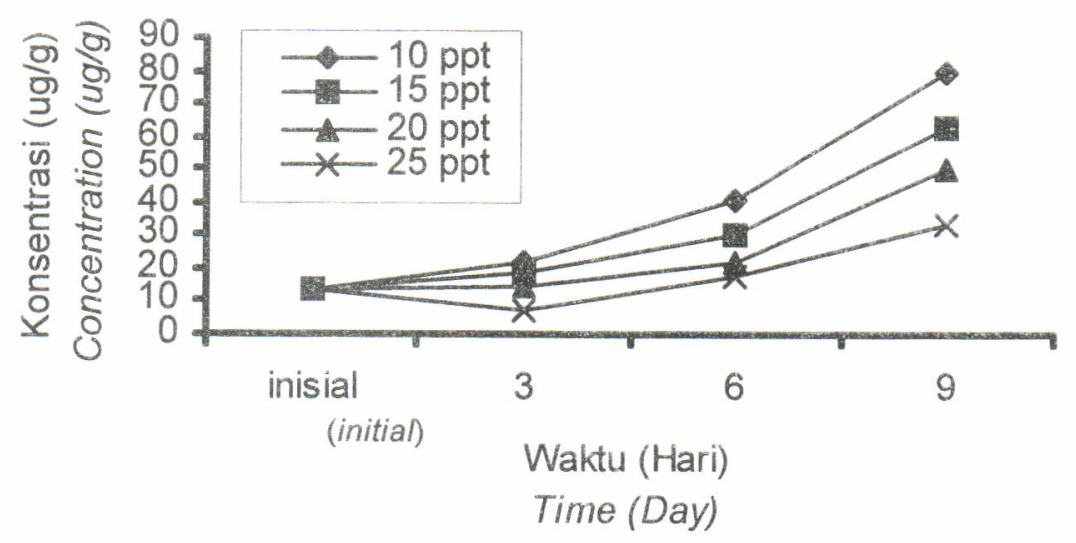

Gambar 3. Akumulasi Pb dalam otak dan usus udang windu pada salinitas berbeda

Figure 3. Accumulation of $\mathrm{Pb}$ in tiger prawn brain and intestine on different salinity

senyawa organik dan anorganik dalam air tawar lebih besar daripada air laut, karena senyawa organik dan anorganik dalam air tawar lebih tinggi. Oleh karena itu potensi pencemaran logam berat di air tawar lebih besar dibandingkan air laut.

Pengambilan awal logam oleh makhluk hidup air dapat terjadi dalam tiga proses utama yaitu dari air melalui permukaan pernafasan (misalnya insang); penyerapan dari air ke dalam permukaan tubuh; dan dari makanan, partikel, atau air yang dicerna melalui sistem pencernaan (Connel \& Miller, 1995). Kecepatan penyerapan dipengaruhi oleh perubahan dalam faktor fisika-kimia, misalnya suhu, $\mathrm{pH}$, dan salinitas dalam ciri-ciri fisiologis dan perilaku makhluk hidup tersebut. Sedangkan pengeluaran logam berat dari dalam tubuh organisme laut melalui dua cara yaitu ekskresi melalui permukaan tubuh dan insang serta melalui isi perut cian urin (Madelli, 1989 dalam Hutagalung, 1991).

Penyerapan logam oleh krustase menurut Connel \& Miller (1995), adalah jika logam larut dalam air melalui permukaan tubuh, misalnya kulit ari, diikuti dengan difusi melalui permukaan, misalnya epitelium insang, mungkin dilekatkan pada ligan organik dan protein dalam. Jika logam masuk bersama makanan maka pada krustase yang lebih besar, misalnya udang karang, penyerapan dari perut atau sistem pencernaan muncul lebih penting. Penyerapan dari larutan tampak paling penting bagi udang dan isopoda-isopoda laut. Namun kandungan logam sedimen juga sangat berpengaruh terhadap bioakumulasi logam, karena krustase selalu bergerak di dasar perairan.

Umumnya makhluk hidup air mampu mengatur kepekatan abnormal logam terutama yang essensial, namun terdapat batas maksimum jumlah logam yang dapat diekskresikan oleh ikan dan krustase apabila terjadi akumulasi dalam jaringan tubuh. Melalui proses tersebut, perbedaan kepekatan logam akan terdeteksi jelas pada spesies tunggal yang diambil dari air yang sama-sama tercemar.

Hasil pengukuran peubah kualitas air selama percobaan menunjukkan kisaran yang layak bagi pertumbuhan dan sintasan udang windu (Tabel 2). Peubah kualitas air dalam penelitian toksikologi berperan penting karena mempunyai pengaruh langsung terhadap perubahan media uji, sehingga dapat berpengaruh terhadap sintasannya. Pengaruh langsung logam berat yang diaplikasikan seperti pengaruh kecerahan air, nafsu makan, densitas sehingga mempengaruhi gerakan hewan uji, sedangkan pengaruh tidak langsung yaitu dapat berinteraksi secara kimiawi dengan unsur lain dalam media, baik hubungan sinergis maupun antagonistik.

\section{KESIMPULAN DAN SARAN}

\section{Kesimpulan}

Berdasarkan hasil penelitian akumulasi $\mathrm{Pb}$ dalam tubuh udang windu, maka dapat disimpulkan sebagai berikut:

1. Akumulasi $\mathrm{Pb}$ dalam jaringan udang windu semakin rendah dengan semakin meningkatnya salinitas dan sebaliknya.

2. Organ otak dan usus udang windu lebih berpotensi mengakumulasi $\mathrm{Pb}$ dibandingkan organ kulit dan daging.

\section{Saran}

Selama operasional budi daya disarankan mempertahankan kondisi salinitas optimal untuk pertumbuhan udang windu agar mengurangi absorpsi $\mathrm{Pb}$ ke dalam tubuhnya. Sedangkan untuk mengantisipasi efek 
Tabel 2. Hasil pengukuran rata-rata kualitas air selama percobaan

Table 2. Average of water quality value during experiment

\begin{tabular}{|c|c|c|c|c|c|}
\hline \multirow{2}{*}{$\begin{array}{c}\text { Pengamatan } \\
\text { (Hari) } \\
\text { Observation } \\
\text { (Day) }\end{array}$} & \multirow{2}{*}{$\begin{array}{l}\text { Parameter } \\
\text { Parameter }\end{array}$} & \multicolumn{4}{|c|}{ Salinitas (Salinity) } \\
\hline & & $10 \mathrm{ppt}$ & $15 \mathrm{ppt}$ & $20 \mathrm{ppt}$ & $25 \mathrm{ppt}$ \\
\hline \multirow{3}{*}{3} & $\begin{array}{l}\text { Suhu }\left({ }^{\circ} \mathrm{C}\right) \\
\text { Temperature }\left({ }^{\circ} \mathrm{C}\right)\end{array}$ & $28.33 \pm 0.48$ & $28.36 \pm 0.47$ & $\begin{array}{c}28.42 \pm \\
0.46\end{array}$ & $28.47 \pm 0.42$ \\
\hline & & $8.39 \pm 0.22$ & $8.5 \pm 0.00$ & $8.33 \pm 0.25$ & $8.33 \pm 0.25$ \\
\hline & $\begin{array}{l}\text { Oksigen terlarut }(\mathrm{mg} / \mathrm{L}) \\
\text { Dissolved oxygen }(\mathrm{mg} / \mathrm{L})\end{array}$ & $3.39 \pm 0.99$ & $4.21 \pm 0.98$ & $4.07 \pm 0.72$ & $4.00 \pm 0.85$ \\
\hline \multirow{3}{*}{6} & $\begin{array}{l}\text { Suhu }\left({ }^{\circ} \mathrm{C}\right) \\
\text { Temperature }\left({ }^{\circ} \mathrm{C}\right)\end{array}$ & $28.44 \pm 0.43$ & $28.50 \pm 0.43$ & $28.6 \pm 0.43$ & $28.63 \pm 0.42$ \\
\hline & $\begin{array}{l}\mathrm{pH} \\
\text { Oksigen terlarut (mo/L) }\end{array}$ & $8.39 \pm 0.22$ & $8.50 \pm 0.00$ & $8.39 \pm 0.22$ & $80.22 \pm 0.39$ \\
\hline & Dissolved oxygen ( $\mathrm{mg} / \mathrm{L}$ ) & $4.57 \pm 0.94$ & $4.46 \pm 0.85$ & $4.42 \pm 0.76$ & $4.21 \pm 0.46$ \\
\hline \multirow{3}{*}{9} & $\begin{array}{l}\text { Suhu }\left({ }^{\circ} \mathrm{C}\right) \\
\text { Temperature }\left({ }^{\circ} \mathrm{C}\right)\end{array}$ & $28.34 \pm 0.50$ & $28.34 \pm 0.47$ & $\begin{array}{c}28.34 \pm \\
0.47\end{array}$ & $28.39 \pm 0.49$ \\
\hline & $\mathrm{pH}$ & $8.75 \pm 0.35$ & $8.50 \pm 0.00$ & $8.39 \pm 0.22$ & $8.33 \pm 0.25$ \\
\hline & $\begin{array}{l}\text { Dissolved oxygen }(\mathrm{mg} / \mathrm{L}) \\
\text { Digen terlarut (mg/L) }\end{array}$ & $4.34 \pm 0.87$ & $4.28 \pm 0.85$ & $4.74 \pm 0.85$ & $4.50 \pm 0.71$ \\
\hline
\end{tabular}

negatif $\mathrm{Pb}$ terhadap kesehatan, maka disarankan membuang kepala dan usus dalam proses pengolahan pascapanen, mengingat jumlah $\mathrm{Pb}$ yang terakumulasi pada kedua organ tersebut sangat tinggi (rata-rata $94,06 \%)$

\section{UCAPAN TERIMA KASIH}

Ucapan terima kasih disampaikan kepada Mirahdyah, Reni Yulianingsih, Rosni, dan Gaffar yang telah membantu pelaksanaan penelitian ini baik di lapangan maupun analisis contoh di laboratorium.

\section{DAFTAR PUSTAKA}

Connel, D.W. 1995. Bioakumulasi Senyawa Xenobiotik. Penerjemah Yanti R.H. Koestoer. Universitas Indonesia Press. 231 pp.

Connel, D.W. dan G.J. Miller. 1995. Kimia dan Ekotoksikologi Pencemaran. UI-Press. 520 pp.

Denton, G.R.W. and C.B. Jones. 1982. The influence of temperature and salinity upon the acut toxicity of heavy metals to the banana prawn (Penaeus merguiensis). Chemistry in Ecology. Macminan Publishing Co., Inc. New York. 619 pp.

Gan, S., B.S. Sunarto, Syamsuddin, R. Setiabudi, dan Setiawati. 1981. Farmakologi dan Terapi. Bagian Farmakologi, Fakultas Kedokteran-Universitas Indonesia. Jakarta. 215 pp.
Huheey, J.E. 1983. Inorganic Chemistry Principles of Structure and Reactivity. Harper International. New York. $543 \mathrm{pp}$.

Hutagalung, H.P. 1991. Pencemaran laut oleh logarn berat. Dalam Djoko Hadi Kunarso \& Ruyitno. Status Pencemaran Laut di Indonesia dan Teknik Pemantauannya. Pusat Penelitian dan Pengembangan Oseanologi-LIPI, Jakarta. p. 45--60.

Kinne, O. 1964. The effect of temperature and salinity in marine and brackishwater animals. Part II. Salinity and temperature salinity combination. Oceanog. Mar. Bio. Ann. Rev. 2:281--339.

Khopkar, S.M. 1990. Konsep Dasar Kimia Analitik. IUPress, Jakarta. 265 pp.

Loomis, T.A. 1978. Toksikologi Dasar (Ed ketiga) Penerjemah Imono Argo Donatus. Penerbit IKIP Semarang Press. $281 \mathrm{pp}$.

Naid, T. dan Seniwati. 1998. Hubungan antara kandungan protein dan logam berat $\mathrm{Pb}, \mathrm{Cd}, \mathrm{Cu}$, dan Zn pada beberapa jenis kerang di perairan Tanjung Bunga, Ujung Pandang. Prosiding Seminar Kelautan LIPI-UNHAS, Ambon 4-6 Juli 1998. p. 266--269.

Palar, H. 1994. Pencemaran dan Toksikologi Logam Berat. Penerbit Rineka Cipta. Jakarta. 152 pp.

Putri, L.S.E. 2001. Pola Penyebaran Spasial dan Temporal Bahan Organik, Logam Berat, dan Pestisida di Perairan Sungai Ciliwung. Disertasi Program Pascasarjana IPB. Bogor. 162 pp. 
Rachmansyah, Dalfiah, P.R. Pong-Masak, dan Taufik Ahmad. 1998. Uji toksisitas logam berat terhadap benur udang windu (Penaeus monodon) dan nener bandeng (Chanos chanos). Jurnal Penelitian Perikanan Indonesia IV(1): 55--66.

Sumeru, S.U. dan S. Anna. 1992. Pakan Udang Windu (Penaeus monodon). Penerbit Kanisius, Yogyakarta.
Waldichuk, H. 1974. Some Biological Concern in Metals Pollution. In Pollution and Physiology of Marine Organisms. Vanberg and Vanberg (eds). Academic Press. London. 217--228 pp. 